\title{
Reliability and Validity of the Enhanced Big Five Personality Test (B5T)
}

\author{
Lars Satow
}

\section{Correspondence:}

Dipl.-Psych. Dr. Lars Satow, M.A.

Untere Auen 7/1, 88677 Markdorf

E-mail: mail@drsatow.de

\section{Copyright \& Citation:}

This work is licensed under a Creative Commons Attribution-NonCommercial-NoDerivatives 4.0 International License.

Date of creation: 31 January 2021

Suggested citation:

Satow, L. (2021, January 31). Reliability and Validity of the Enhanced Big Five Personality Test (B5T). https://doi.org/10.31234/osf.io/wsugv 


\begin{abstract}
The Big Five Personality Test (B5T) was first developed in 2010 with the aim of measuring the five fundamental personality dimensions of Neuroticism (N), Extraversion (E), Conscientiousness (C), Agreeableness (A) and Openness (O) (Allport, 1937; Cattell, 1957, 1965; Eysenck, 1947; Goldberg, 1981, 1993; Norman, 1963; Tupes \& Christal, 1961). With a convincing factorial structure and high reliability (Cronbach's Alpha), it was shorter than previous procedures (McCrae \& Costa, 2004) and was also suitable for use in a professional context (career counseling, personnel selection, personnel development, coaching). In order to also measure the potential and direction of a person, the inventory was later supplemented by three scales for capturing the basic needs for achievement (achievement motive), power (power motive) and security (security motive). After a first large standardization and validation study in 2012, the inventory was re-examined during 2020 using a large sample ( $n=$ 21,048). All scales achieved convincing psychometric values (Conrbach's alpha between .76 and .90), which hardly differed from the values from 2012. The factorial structure could be confirmed in confirmatory factor analyzes. There were clear connections with occupation, which suggest that the enhanced inventory is suitable for use in a professional context. The B5T is licensed under a Creative Commons Attribution-NonCommercial-NoDerivatives 4.0 International License. All language versions and further details are available from www.drsatow.de
\end{abstract}

Keywords: Big Five factor model, need for achievement, need for power, need for security, personality dimensions, personality assessment. 


\section{Reliability and Validity of the Enhanced Big Five Personality Test (B5T)}

A first version of the Big Five Personality Test (B5T) was developed in 2010 with the aim of measuring the five fundamental personality dimensions of Neuroticism $(\mathrm{N})$, Extraversion $(\mathrm{E})$, Conscientiousness (C), Agreeableness (A) and Openness (O) (Allport, 1937; Cattell, 1957, 1965; Eysenck, 1947; Goldberg, 1981, 1993; Norman, 1963; Tupes \& Christal, 1961). With a convincing factorial structure and high reliability (Cronbach's alpha), it was shorter than previous inventories (cf. McCrae \& Costa, 2004) and was suitable for use in a professional context (career counseling, personnel selection, personnel development, coaching). At the same time, the B5T was one of the first inventories that could be used free of charge for non-commercial purposes under an CC license. Since then, more than a hundred studies, bachelor's and master's theses have dealt with the inventory, validating its structure and scales, and examining the diverse relationships between personality, motives, and behavior. The inventory is offered on several test platforms and, with more than 20,000 tests carried out per year, is one of the most frequently used assessments. The main areas of application of the B5T range from career counseling and coaching to clinical diagnostics.

In order to also measure a person's potential and direction of development, the inventory was later supplemented by three scales for capturing the basic needs for achievement (achievement motive), power (power motive) and security (security motive). In addition, the B5T features several mechanisms for preventing biased results: The test includes a scale to control faking good through positive self-presentation and, since the 2020 version, a plausibility check that detects conspicuous, implausible response patterns. The present study presents selected results for the structural validity of the inventory - especially regarding the three additional scales for measuring the basic needs.

\section{Development of the enhanced Big Five Personality Test (B5T)}

The B5T is a theoretically well-founded big five personality inventory that has been developed according to the stipulations of classical test theory. The first version of the B5T was developed by Dr. Satow in German in 2010 and comprised 70 items (14 per personality dimension). Already with this first version, special attention was paid to use in a professional context. All items were formulated as statements that can be agreed with on a four-point scale from 1 (does not apply at all) to 4 (applies exactly). When formulating the items, care was taken to ensure that the items were not perceived as too private, inappropriate, or unpleasant. The 2010 version was later included in the electronic test library of the Leibniz Institute for Psychology (ZPID) which is the supra-regional scientific research support organization for psychology in German-speaking countries (Satow, 2011). 
In 2012 the version was optimized based on a large sample $(n=5,520)$ (Satow, 2012). For the 2012 version, the number of items on personality could be reduced from 70 to 50 - with even better psychometric quality criteria. To measure the potential and direction of a person, three scales with 6 items each for recording the basic needs for achievement (achievement motive), power and influence (power motive) and security (security motive) were added. With the 2020 version, the total of 72 items of the 2012 version have been retained unchanged except for minor linguistic adjustments (Appendix). New are a plausibility check that detects suspicious response patterns, as well as language versions for Spanish, Italian and French (Satow, 2020). All language versions and further details are available from www.drsatow.de

\section{Structure of the Enhanced Big Five Personality Test (B5T)}

While the Big Five personality dimensions describe the structure of a personality phenotypically, the basic motives can provide information about the direction of development and the potential of a person. A first approach to the systematization of motifs originated from Murray (1938). He created a list of basic human needs that vary from person to person, including the need for achievement, which has been studied extensively over many years. Murray also developed a first test to measure achievement motive, which was later further improved by McClelland (1958). McClelland (1987) was convinced that in addition to the achievement motive, two other motives are of particular importance: the power motive and the social need of belonging. However, the latter in particular can also be seen as a component of Extraversion (Costa \& McCrae, 1985; Jha, 2010). In Maslow's pyramids of needs (1943), it is one of the psychological needs of higher order.

Reiss (2008) later determined 16 basic needs by means of factor analysis, including the needs for power, for recognition and for security. However, many test items in the Reiss profile are unsuitable for professional aptitude testing. Other items are obviously more geared towards personality than needs. Thus, Boyd (2010) was able to show in her thesis that the Reiss profile can largely be traced back to the Big Five factors. To measure potential and direction of development, the B5T therefore includes three basic motives that cannot be traced back to the Big Five dimensions, but rather complement them:

Achievement motive (nA): People with a strong achievement motive always try to do their best. They are only satisfied when they have achieved their goals. At the same time, they are looking for recognition for their performance and are ready to forego many conveniences for success. Example item: "I have always felt a strong need for recognition and admiration." 
Power motive (nP): People with a great need for power want to leave their mark on the world. They want to shape and take responsibility. They are only satisfied when they can control and influence important decisions. Example item: " To have more influence, I would give up a lot of things."

Security motive (nS): People with a pronounced need for security, long for (inner) peace, order and secure relationships. They do not like surprises and when given a choice, they go for safety and against risk. Example item: " Deep inside, I long for safety and peacefulness."

\section{Method and Sample}

To validate the inventory, psychometric scale parameters (selectivity, Cronbach's alpha) and the interscale correlations were determined in a first step. The factorial structure of both the Big Five scales and the motive scales was then validated using a confirmatory factor analysis. Finally, the relationships between the scales and occupation were analyzed. All statistical analyzes were carried out with the statistics program $\mathrm{R}$ (R Core Team, 2020) version 4.0.3.

The sample was obtained with the help of the online portal Psychomeda, on which the B5T is offered as a free and anonymous self-test. All visitors to the portal can take part in the test without registering. Some demographic data is collected before the test. In addition, the participants are asked whether they intend to answer the test truthfully or "just try it out". The test result is displayed with detailed explanations immediately after the last test item.

In the period from June 2019 to July 2020, the B5T was carried out a total of 23,912. After the gradual exclusion of non-usable cases, 21,048 data records remained in the validation sample. Most cases $(n=2,702)$ were excluded because people indicated that they "only wanted to try the test" or because they had already taken the test several times. Most of the persons in the validation sample were female $(n=13,123)$, between 20 and 30 years old $(n=7,547)$, had a high school diploma $(n=$ $9,275)$ and were employed $(n=8,758)$. 


\section{Results}

Table 1 shows the most important scale parameters. The reliability (Cronbach's alpha) for the Big Five scales ranged between $\alpha=.76$ and .90 . The reliability of the motive scales between $\alpha=.71$ and .81. Overall, there were hardly any deviations from the values determined in 2012 . The exclusion of items would not have led to a further improvement in reliability for any scale.

Table 1. Psychometric parameters of B5T scales

\begin{tabular}{|l|c|c|c|c|c|c|c|c|}
\hline Scale & Items & M & SD & Median & Min & Max & $\begin{array}{c}\text { Cronbach's } \\
\text { Alpha }\end{array}$ & $\sigma_{\mathrm{e}}$ \\
\hline Neuroticism (N) & 10 & 26.01 & 6.62 & 26 & 10 & 40 & $.90(.90)$ & 2.09 \\
\hline Extraversion (E) & 10 & 25.84 & 5.81 & 26 & 10 & 40 & $.86(.87)$ & 2.17 \\
\hline Conscientiousness (C) & 10 & 26.78 & 4.62 & 27 & 10 & 40 & $.76(.77)$ & 2.26 \\
\hline Openness (O) & 10 & 28.66 & 4.93 & 29 & 10 & 40 & $.76(.76)$ & 2.42 \\
\hline Agreeableness (A) & 10 & 30.92 & 3.94 & 31 & 15 & 40 & $.78(.76)$ & 1.85 \\
\hline Need for Achievement (nA) & 6 & 14.71 & 3.85 & 15 & 6 & 24 & $.81(.82)$ & 1.68 \\
\hline Need for Power (nP) & 6 & 12.74 & 3.65 & 12 & 6 & 24 & $.77(.78)$ & 1.75 \\
\hline Need for Security (nS) & 6 & 17.90 & 3.52 & 18 & 6 & 24 & $.83(.84)$ & 1.45 \\
\hline Note: In brackets values fro
\end{tabular}

Note: In brackets values from 2012.

Neuroticism (N): As in 2012, the Neuroticism scale achieved an extremely high value for the test accuracy (reliability) in the present sample with Cronbach's $\alpha=.90$. The item with the highest selectivity was in turn " I often feel insecure."

The Extraversion (E) scale also impressed with its measurement accuracy (Cronbach's $\alpha=.86$ ). Since Introversion is the opposite of extraversion, the scale also features two negatively polarized items. As in 2012, the item with the greatest selectivity was "I am very sociable."

As in 2012, the Conscientiousness (C) scale achieved a good value for test accuracy with Cronbach's $\alpha=.76$. The item with the highest selectivity was in turn "I always complete my tasks very accurately."

The Openness $(\mathrm{O})$ scale encompasses not only curiosity, imagination, and inventiveness, but also the preference for art, music, and philosophical topics. As in 2012, with Cronbach's $\alpha=.76$, it again achieved good reliability in this validation sample. The item with the highest selectivity was again "I always enjoy learning new things." 
With a value of Cronbach's $\alpha=.78$, the Agreeableness scale (A) achieved a slightly better value in the validation sample. The item with the highest selectivity this time was "I make sure to always be friendly."

Although the scale for measuring the need for achievement (nA) only includes six items, it again achieved an incredibly good value for reliability with Cronbach's $\alpha=.81$. The item with the greatest selectivity was " I have always felt a strong need for recognition and admiration."

As in the 2012 sample, the power motive (nP) scale (need for influence and power) again achieved a good value for test accuracy (reliability) with Cronbach's $\alpha=.77$ despite its brevity. The item with the highest selectivity was "To have more influence, I would give up a lot of things."

Like the other two scales for basic needs, the security motive (nS) scale (need for security and order) achieved a remarkable level of reliability in this sample (Cronbach's $\alpha=.83$ ). The item with the highest selectivity was "Deep inside, I long for safety and peacefulness."

\section{Interscale Correlations}

The interscale correlations provided indications of the validity of the content of the B5T scales. On the one hand, they should correspond to the theoretical expectations; on the other hand, they should not be too high. High interscale correlations would indicate overlapping of the scales. The correlation matrix (Table 2) shows that this was not the case. The highest correlations were found between the scales of achievement motive and power motive $(r=.57)$ and between Neuroticism and the security motive $(r=.45)$ : Achievement-motivated people often also have a higher need for power and influence. Anxious, unstable people have a greater need for security and peace.

Tabelle 2. Interscale correlations

\begin{tabular}{|l|c|c|c|c|c|c|c|c|}
\hline & $\mathrm{N}$ & $\mathrm{E}$ & $\mathrm{C}$ & $\mathrm{O}$ & $\mathrm{A}$ & $\mathrm{nA}$ & $\mathrm{nP}$ & $\mathrm{nS}$ \\
\hline $\mathrm{N}$ & 1 & & & & & & & \\
\hline $\mathrm{E}$ & -.35 & 1 & & & & & & \\
\hline $\mathrm{C}$ & -.07 & -.01 & 1 & & & & & \\
\hline $\mathrm{O}$ & -.20 & .33 & -.03 & 1 & & & & \\
\hline $\mathrm{A}$ & -.10 & .25 & .23 & .13 & 1 & & & \\
\hline $\mathrm{LM}$ & .12 & .18 & .05 & .24 & -.18 & 1 & & \\
\hline $\mathrm{MM}$ & -.13 & .21 & .06 & .32 & -.16 & .57 & 1 & \\
\hline $\mathrm{SM}$ & .45 & -.24 & .23 & -.25 & .14 & -.03 & -.21 & 1 \\
\hline
\end{tabular}

Note: All correlations are statistically significant $(p<.05)$. 


\section{Structural Validity}

To validate the factorial structure of the B5T, an exploratory factor analysis was carried out during the first validation in 2012 (Satow, 2012). The results confirmed both the number of factors and the item structure on which the test was based. However, an exploratory factor analysis is only a weak criterion for validating the Big Five structure, as it allows all factor loads. The confirmatory factor analysis (CFA) enables a much stricter test: It can not only check the number of factors, but also the assumption that each item is exclusively assigned to one factor.

For the present validation, the scale model of the B5T was validated with the strictest conceivable model with the help of a confirmatory factor analysis: Five factors, each item being assigned to exactly one factor and the measurement errors (residuals) being uncorrelated. This model already achieved a good fit $(\mathrm{CFI}=.84 ; \mathrm{RMSEA}=.07 ; \mathrm{SRMR}=.07)$. DWLS was used as the fit function due to the four-level answer options. Almost all items achieved factor loadings of $\mathrm{a}_{\mathrm{jk}}=.30$ and more. Only four items could not convince in this respect. Overall, the confirmatory factor analysis, like the exploratory factor analysis in 2012, again confirmed the scale model of the B5T with five factors and 1:1 assignment of the items to their respective scale.

In addition to the five Big Five scales, which are each measured with 10 items, the B5T also includes three scales for the three basic motives need for achievement (nA), need for power (nP) and need for security (nS). The scale model of these basic motives was also checked with the help of a strict confirmatory factor analysis. The model achieved an exceptionally good fit straight away $(\mathrm{CFI}=.96$; RMSEA $=.06 ;$ SRMR $=.05)$. All items, except for one, achieved factor loadings of $a_{\mathrm{jk}}=.30$ and higher on their respective scale. Also, the scale model of the basic motives was confirmed by a strict test (3 factors; one-to-one assignment of the items; uncorrelated residuals).

\section{Relationship with Occupation}

As in 2012, the current sample also found significant relationships with education, occupation, and income for all B5T scales. All differences were verified by analyzes of variance and are highly significant with $p<0.01$. The differences are particularly characteristic (Figure 1): Self-employed achieved the highest values for Openness $(\mathrm{O})$ and the lowest for Neuroticism $(\mathrm{N})$. Students achieved the second highest values for Openness (O). Civil servants had the highest scores for Conscientiousness $(\mathrm{C})$ and the second lowest scores for Neuroticism $(\mathrm{N})$. Blue-collar workers and unemployed showed high scores for Neuroticism $(\mathrm{N})$ but only low scores for Openness $(\mathrm{O})$ and Extraversion (E). 


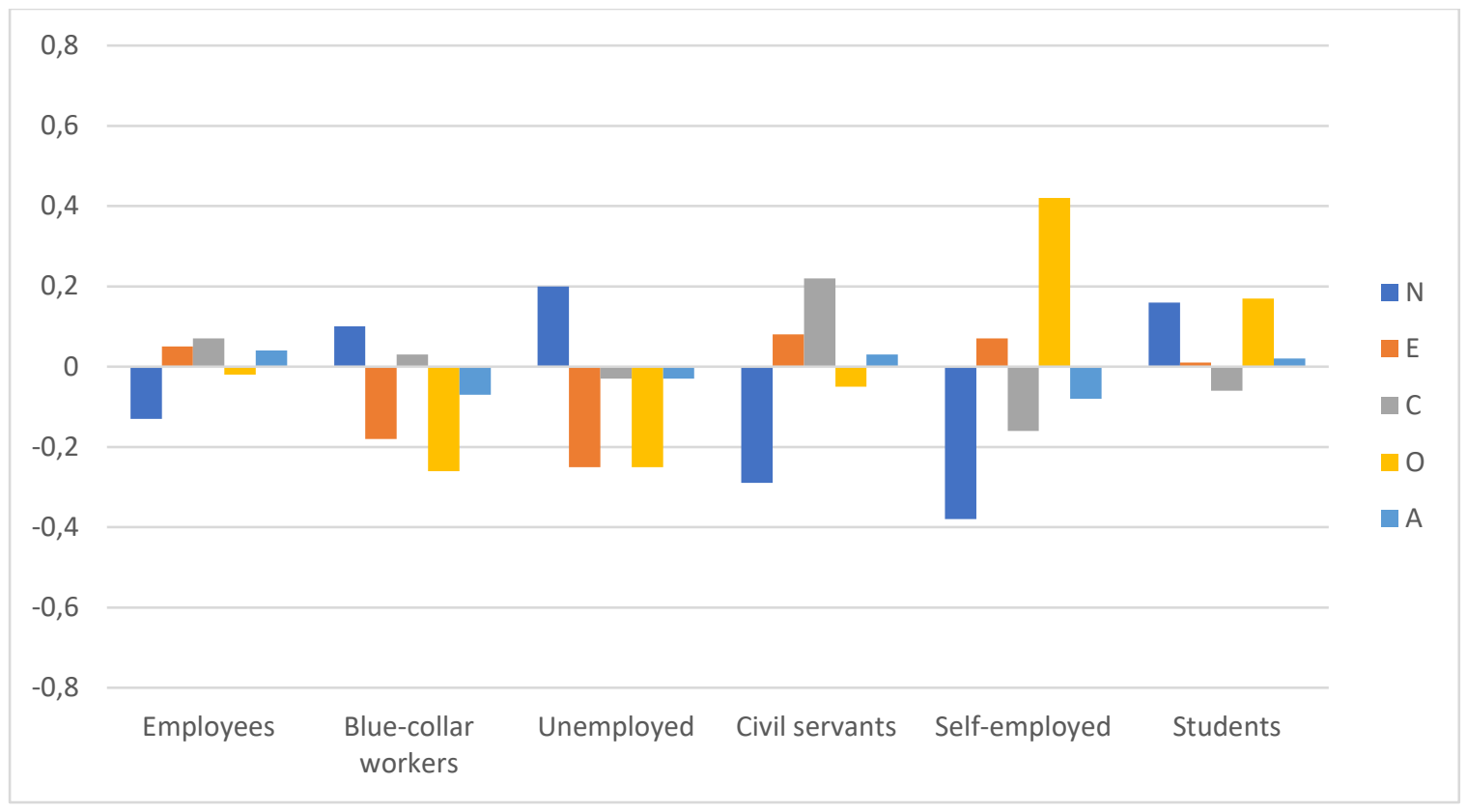

Figure 1. Big five scales and occupation

Typical patterns were also found for the basic motives, which not least speak for the validity of these scales: The self-employed have the highest values for the power motive (nP) and the lowest for the security motive $(\mathrm{nS})$. Students scored the highest for achievement motive (nA). Unemployed people showed the highest values for the security motive (nS) and the lowest for the achievement motive (nA).

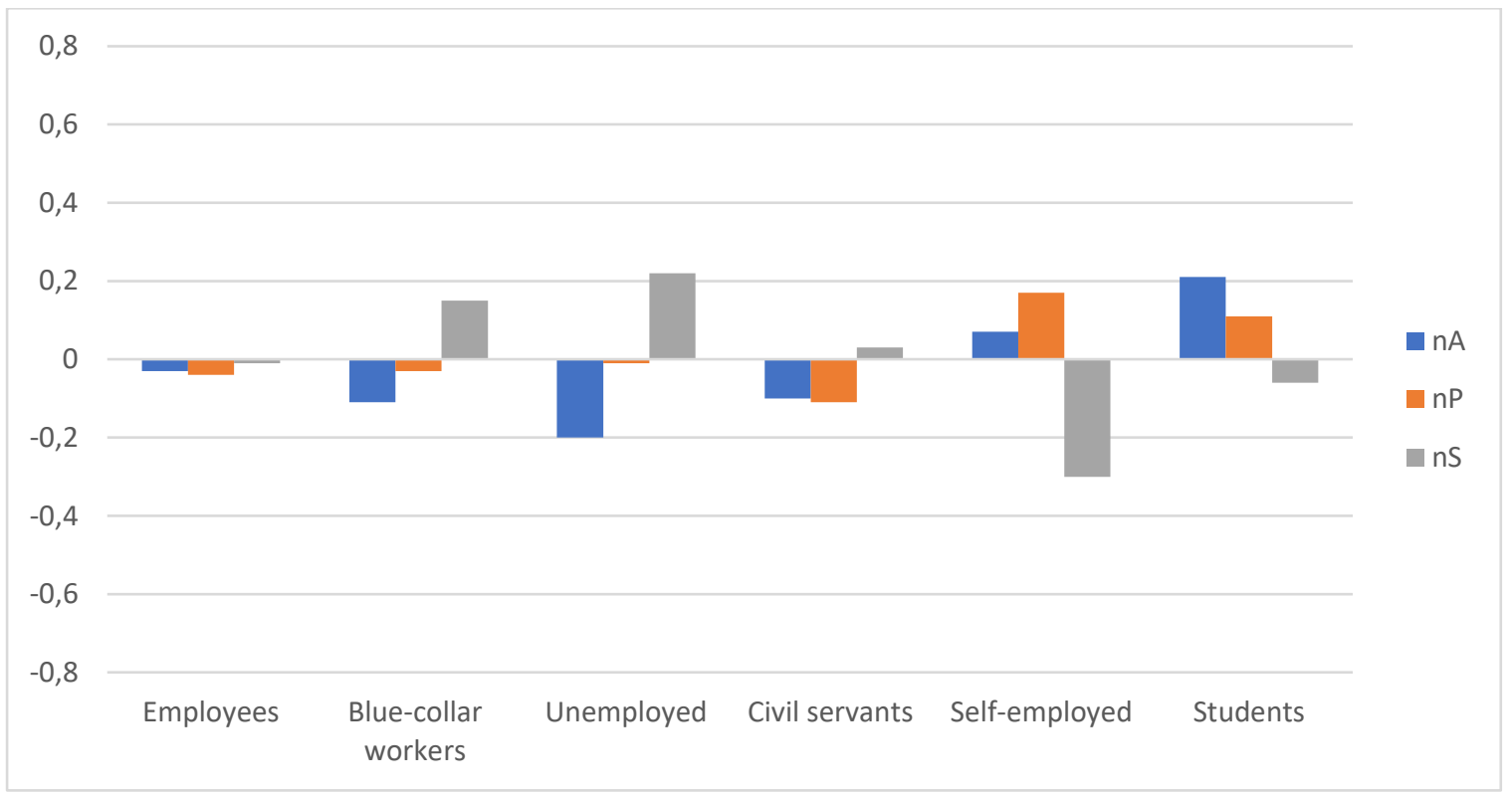

Figure 2. Motive scales and occupation 


\begin{abstract}
Summary
The B5T was developed to measure the five basic personality dimensions (Big Five). The inventory was later expanded to include three scales to capture the basic motives of achievement, security, and power. After an initial validation in 2012, the inventory was subjected to another validation using a large sample $(n=21,048)$. The scales achieved convincing psychometric parameters for reliability (Conrbach's alpha between .76 and .90), which hardly differed from the parameters from 2012. Both the most selective items and the interscale correlations speak for the content validity. The factorial structure could also be confirmed in confirmatory factor analyzes. There were clear connections with occupation, which also suggest that the inventory is suitable for use in a professional context. The self-employed, for example, achieved the highest values for Openness and need for power, but the lowest for Neuroticism (N). Civil servants had the highest scores for Conscientiousness (C) and the second lowest scores for Neuroticism $(\mathrm{N})$. Students scored the highest for achievement motive (nA). Unemployed people had the highest values for the security motive $(\mathrm{nS})$ and the lowest for the achievement motive (nA).
\end{abstract}

In summary, the B5T was validated and its scales were confirmed in a sample with more than 21,000 participants thanks to its good scale parameters and its confirmed factorial structure. The inclusion of three further scales for the basic motives need for achievement, security and power makes it possible to measure not only the phenotypic structure of personality (Big Five factores), but also the inner drive and thus the direction of development and potential. 


\section{Appendix}

\section{B5T Scales with Item-Test Correlations (Item selectivity)}

The B5T is licensed under a Creative Commons Attribution-NonCommercial-NoDerivatives 4.0

International License. All language versions and further details are available from www.drsatow.de

Neuroticism scale $(\mathrm{N})$

\begin{tabular}{|l|c|c|c|}
\hline & $M$ & $S D$ & $r_{\text {it }}$ \\
\hline I am a fearful person. & 2.4 & 0.83 & .69 \\
\hline I often feel insecure. & 2.5 & 0.93 & .81 \\
\hline I often feel an inner restlessness. & 2.6 & 0.96 & .73 \\
\hline I often worry unnecessarily. & 2.9 & 0.93 & .74 \\
\hline I think a lot about my future. & 3.1 & 0.86 & .57 \\
\hline I often feel overwhelmed by my feelings. & 2.7 & 0.93 & .69 \\
\hline I am often sad for no reason. & 2.3 & 1.01 & .75 \\
\hline I am often nervous. & 2.5 & 0.89 & .75 \\
\hline I am often torn apart by my feelings. & 2.6 & 0.92 & .74 \\
\hline I often feel uncertain about my decisions. & 2.6 & 0.92 & .72 \\
\hline
\end{tabular}

Extraversion scale (E)

\begin{tabular}{|l|l|l|l|}
\hline Item & $M$ & $S D$ & $r_{\text {it }}$ \\
\hline I enjoy being with other people. & 3.0 & 0.81 & .78 \\
\hline I can quickly spread a good mood. & 2.8 & 0.82 & .64 \\
\hline I am an adventurous person. & 3.0 & 0.79 & .68 \\
\hline I like to be the center of attention. & 2.1 & 0.88 & .55 \\
\hline Usually, I prefer to be alone by myself. (-) & 2.5 & 0.88 & .71 \\
\hline I am a loner. (-) & 2.7 & 0.93 & .70 \\
\hline I like to go to parties. & 2.4 & 0.99 & .62 \\
\hline I am active in many clubs. & 1.6 & 0.83 & .45 \\
\hline I am a talkative and communicative person. & 3.0 & 0.86 & .73 \\
\hline I am very sociable. & 2.8 & 0.89 & .81 \\
\hline
\end{tabular}


Conscientiousness scale (C)

\begin{tabular}{|l|l|l|l|}
\hline & $M$ & $S D$ & $r_{\text {it }}$ \\
\hline I am a very dutiful person. & 3.2 & 0.78 & .67 \\
\hline I always complete my tasks very accurately. & 3.1 & 0.71 & .70 \\
\hline Even as a child I was very neat. & 2.2 & 0.96 & .56 \\
\hline I always take a systematic approach. & 2.7 & 0.81 & .66 \\
\hline I have my principles and stick to them. & 2.9 & 0.75 & .49 \\
\hline Even small fines make me uncomfortable. & 2.6 & 1.06 & .38 \\
\hline Even small sloppiness bothers me. & 2.5 & 0.85 & .59 \\
\hline I make sure the rules are being followed. & 2.8 & 0.79 & .65 \\
\hline Once I have made a decision, I stick with it. & 2.6 & 0.76 & .44 \\
\hline I never make careless mistakes. & 2.2 & 0.76 & .51 \\
\hline
\end{tabular}

Openness scale $(\mathrm{O})$

\begin{tabular}{|l|l|l|l|}
\hline Item & $M$ & $S D$ & $r_{\text {it }}$ \\
\hline I always want to try new things. & 2.9 & 0.81 & .63 \\
\hline I am a curious person. & 3.3 & 0.69 & .60 \\
\hline I travel a lot to get to know new cultures. & 2.4 & 1.01 & .49 \\
\hline I would prefer everything to stay as it is. (-) & 2.7 & 0.85 & .48 \\
\hline I like to discuss. & 2.9 & 0.90 & .49 \\
\hline I always enjoy learning new things. & 3.3 & 0.69 & .67 \\
\hline I deal a lot with art, music and literature. & 2.6 & 0.98 & .54 \\
\hline I am very interested in philosophical questions. & 2.8 & 1.01 & .57 \\
\hline I read a lot about scientific topics, new discoveries or & 2.6 & 1.02 & .58 \\
\hline historical events. & & & .58 \\
\hline I have many ideas and a vast imagination. & 3.1 & 0.80 & \\
\hline
\end{tabular}


Agreeableness scale (A)

\begin{tabular}{|l|l|c|c|}
\hline Item & $M$ & $S D$ & $r_{\text {it }}$ \\
\hline I make sure to always be friendly. & 3.3 & 0.68 & .67 \\
\hline I am a polite person. & 3.5 & 0.60 & .64 \\
\hline I help others, even if it does not get appreciated. & 3.2 & 0.70 & .60 \\
\hline I am repeatedly having disputes with others. (-) & 3.2 & 0.77 & .52 \\
\hline I am a selfish person. (-) & 3.0 & 0.84 & .58 \\
\hline I always show gratefulness if somebody helps me. & 3.5 & 0.59 & .57 \\
\hline I would never let my bad mood affect others. & 2.5 & 0.82 & .48 \\
\hline I can easily put my needs aside for others. & 2.8 & 0.80 & .58 \\
\hline I am very good at putting myself in somebody's & 3.3 & 0.75 & .55 \\
\hline position. & & & .62 \\
\hline I get along well with others, even if they do not & 2.9 & 0.71 & \\
\hline share my opinion. & & & \\
\hline
\end{tabular}

Need for Achievement scale (nA)

\begin{tabular}{|l|c|c|c|}
\hline Item & $M$ & $S D$ & $r_{\text {it }}$ \\
\hline $\begin{array}{l}\text { I have always felt the strong need to be the best } \\
\text { according to my own standards. }\end{array}$ & 2.9 & 0.90 & .63 \\
\hline $\begin{array}{l}\text { I have always felt a strong need for recognition and } \\
\text { admiration. }\end{array}$ & 2.6 & 0.89 & .81 \\
\hline I would give up a lot for more admiration. & 2.0 & 0.78 & .69 \\
\hline $\begin{array}{l}\text { I am happiest when many people admire me and like } \\
\text { what I do. }\end{array}$ & 2.6 & 0.86 & .73 \\
\hline Deep inside, I long to be the best. & 2.7 & 0.99 & .77 \\
\hline I often dream of being famous. & 2.0 & 0.96 & .65 \\
\hline
\end{tabular}


Need for Power scale (nP)

\begin{tabular}{|l|c|c|c|}
\hline Item & $M$ & $S D$ & $r_{\text {it }}$ \\
\hline $\begin{array}{l}\text { I often dream of making important decisions for } \\
\text { politicians or other powerful people. }\end{array}$ & 1.8 & 0.92 & .74 \\
\hline $\begin{array}{l}\text { If I had the choice, I would like to make decisions of } \\
\text { great importance in my life. }\end{array}$ & 2.5 & 0.95 & .73 \\
\hline $\begin{array}{l}\text { Deep inside, I long for power and influence. } \\
\begin{array}{l}\text { To have more influence, I would give up a lot of } \\
\text { things. }\end{array}\end{array}$ & 2.2 & 0.93 & .75 \\
\hline $\begin{array}{l}\text { I am happiest when I can take responsibility and } \\
\text { make important decisions. }\end{array}$ & 2.6 & 0.86 & .76 \\
\hline $\begin{array}{l}\text { I can understand people, who state that there are } \\
\text { things, which are more important than power and }\end{array}$ & 1.7 & 0.75 & .64 \\
\hline \begin{tabular}{l} 
politics. (-) \\
\hline
\end{tabular} & & & .48 \\
\hline
\end{tabular}

Need for Security scale (nS)

\begin{tabular}{|c|c|c|c|}
\hline & $M$ & $S D$ & $r_{\text {it }}$ \\
\hline $\begin{array}{l}\text { I have always felt a strong need for safety and } \\
\text { quietness. }\end{array}$ & 3.0 & 0.80 & .74 \\
\hline $\begin{array}{l}\text { If I had the choice, I would choose to live in security } \\
\text { and peace. }\end{array}$ & 3.2 & 0.76 & .75 \\
\hline $\begin{array}{l}\text { I would give up a lot for a safe life without any bad } \\
\text { surprises. }\end{array}$ & 2.5 & 0.81 & .71 \\
\hline Deep inside, I long for safety and peacefulness. & 3.2 & 0.76 & .79 \\
\hline $\begin{array}{l}\text { Often, I dream of a peaceful life without any nasty } \\
\text { surprises. }\end{array}$ & 2.8 & 0.94 & .71 \\
\hline I am happiest, when I feel safe. & 3.2 & 0.74 & .68 \\
\hline
\end{tabular}




\section{References}

Allport, G. W. (1937). Personality: A psychological interpretation. New York: Henry Holt.

Boyd, S. E. (2010). A Comparison of the Reiss Profile with the NEO PI-R Assessment of Personality. University of Kentucky Master's Theses. 73. Verfügbar unter https://uknowledge.uky.edu/gradschool_theses/73

Cattell, R. B. (1957). Personality and Motivation Structure and Measurement. New York: World Book.

Cattell, R. B. (1965). The Scientific Analysis of Personality. London: Penguin.

Costa, P. T., Jr. \& McCrae, R. R. (1985). The NEO Personality Inventory Manual. Odessa, FL: Psychological Assessment Resources.

Eysenck, H. J. (1947). Dimensions of Personality. London: Routledge \& Kegan Paul.

Goldberg, L. R. (1981). Language and individual differences: The search for universals in personality lexicons. In Wheeler (Ed.), Review of Personality and social psychology, Vol. 1, 141-165. Beverly Hills, CA: Sage.

Goldberg, L. R. (1993). The Structure of Phenotypic Personality Traits. American Psychologist, 48(1), 26-34.

Jha, S. (2010). Need for growth, achievement, power and affiliation: Determinants of psychological empowerment. Global Business Review, 11(3), 379-393.

Maslow, A.H. (1943). A theory of human motivation. Psychological Review, 50(4), 370-96.

Maslow, A. H. (1971). The farther reaches of human nature (Vol. 19711). New York: Viking Press. 
McClelland, D. C. (1958). Methods of measuring human motivation. In J. W. Atkinson (Ed.), Motives in fantasy, action, and society (pp. 7-42). Princeton, NJ: D. Van Nostrand Company, Inc.

McClelland, D. C. (1987). Human motivation. CUP Archive.

McCrae, R. R., \& Costa Jr, P. T. (2004). A contemplated revision of the NEO Five-Factor Inventory. Personality and individual differences, 36(3), 587-596.

Murray, H. A. (1938). Explorations in personality. New York: Oxford University Press

Norman, W. T. (1963). Toward an adequate taxonomy of personality attributes: Replicated factor structure in peer nomination personality ratings. Journal of Abnormal and Social Psychology, 66, 574-583.

R Core Team (2020). $R$ : A language and environment for statistical computing. R Foundation for Statistical Computing, Vienna, Austria. URL https://www.R-project.org/.

Reiss, S. (2008). The Normal Personality: A New Way of Thinking about People. Cambridge University Press.

Satow, L. (2011). Big-Five-Persönlichkeitstest (B5T). In Zentrum für Psychologische Information und Dokumentation (ZPID) (Hrsg.), PSYNDEX (OnlineDatenbanksegment PSYNDEX Tests Dok.-Nr. 9006357). Trier: ZPID.

Satow, L. (2012). Big-Five-Persönlichkeitstest (B5T): Test- und Skalendokumentation. Verfügbar unter http://www.drsatow.de.

Satow, L. (2020). Big-Five-Persönlichkeitstest (B5T): Test- und Skalendokumentation. Verfügbar unter http://www.drsatow.de.

Tupes, E. C, \& Christal, R. E. (1961). Recurrent personality factors based on trait ratings (USAF ASD Tech. Rep. No. 61-97). Lackland Air Force Base, TX: U.S. Air Force. 